\title{
The Effect of Transparency, Accountability and Commitment Organization on Budget Quality with Leadership Style as a Moderating Variables on Government of North Sumatera
}

\author{
Veby Zoraya Fikri Lubis ${ }^{1)^{*}}$, Erlina ${ }^{2)}$, Khaira Amalia Fachrudin ${ }^{3)}$ \\ 1), 2),3) Department of Accounting, Faculty of Economics and Business, Universitas Sumatera Utara, Medan, Indonesia
}

\begin{abstract}
This study aims to evaluate the effect of transparency, accountability, and organizational commitment on budget quality with leadership style as a moderating variable on Government of North Sumatera. The population in this study amounted to 51 OPDs in the Provincial Government of North Sumatra, with the sampling technique using saturated samples where all populations were sampled. This study's results indicate that transparency affects budget quality, accountability affects budget quality, and organizational commitment affects budget quality in the Provincial Government of North Sumatra. Meanwhile, leadership style cannot moderate the relationship between transparency and budget quality. Leadership style can moderate the relationship between accountability for budget quality, and leadership style cannot moderate the relationship between organizational commitment to budget quality on Government of North Sumatera.
\end{abstract}

Keywords:- Transparency, accountability, organizational commitment, budget quality, leadership style.

\section{INTRODUCTION}

The Regional Budget (APBD) is an annual regional government financial plan discussed and approved by the local government and DPRD and stipulate by provincial regulations. The APBD is used as one of the main highlights by the community to measure the performance of their respective local governments. It can be seen the preparation and realization of the APBD are following with no expectations of the community. To make this happen, local governments can fulfill this by compiling a work plan, and budget for regional apparatus organizations (RKA OPD) as referred to in Law Number 17 of 2003 concerning State Finance articles 19 (1) and (2), namely, an approach based on work performance that will achieve. And it must also be supported by quality resources in the sense of having competence in their field, namely with an adequate educational background, having a strong motivation to do their job, and supported by related regulations and policies.

Local governments must improve the quality of financial management, especially improving the quality of planning and budgeting to improve public services and welfare (Erlina, Tarigan, Muda, 2017). Budget quality is a budget allocation in favor of the needs of the community. Some of the basic principles that must accommodate in budgeting for quality are transparent, participatory, disciplined, fairness, efficiency, and effectiveness, as well as rational and measurable (Rinusu, 2003). The principles of regional budgets are legislative authorization, comprehensive, budget integrity, periodic, accurate, precise, and public knowledge. Budgeting, carried out by these fundamental principles, is expected to create a quality budget (Munir, 2003).

Several studies examining the quality of budgets based on their characteristics, among others, were carried out by Kenis (1979). Their results showed that overall the characteristics of budget targets (participation, clarity of targets, feedback, evaluation, and difficulty level of budget targets) played an essential role in developing/improving attitudes/behavior towards budget. Participation and clarity of budget targets have a positive and significant effect on managers' attitudes/behaviors towards budgets. The same results obtain for budget motivation and performance.

The conclusion from the above description is that the change in regional financial management is a logical consequence of the application of local autonomy and demands a budget reform, which it creates a shift from the traditional budget to the performance budget, given the importance of budget quality and the factors that affect it, especially in the current regional financial management. This research will be more focused in terms of transparency, accountability and organizational commitment as well as leadership style, so that for the preparation of this thesis the researcher takes the title of the influence of transparency, accountability and organizational commitment on-budget quality with leadership style as a moderating variable on Government of North Sumatera.

\section{LITERATURE REVIEW}

\section{A. Agency Theory}

Agency theory is a contract between someone or more referred to as a Principal that appoints another party called an Agent to carry out duties under the principal's interests, including the delegation of some decision-making authority to the Agent (Jensen and Meckling, 1976). 
Public sector agency theory is used to analyze the principal-agent relationship concerning public sector budgeting (Abdullah and Asmara, 2006). Agency theory explains the contractual arrangement between two or more individuals, groups, or organizations. One of the parties (principal) makes a contract, either implicitly or explicitly, with other parties (agents) in the hope that the agent will act/do the job as desired by the principal (Jensen and Meckling, 1976).

\section{B. Stewardship Theory}

Stewardship theory is a theory that describes a situation where managers are not motivated by individual goals but instead aimed at their main outcome goals for the benefit of the organization, so this theory has a psychological and sociological basis that has designed in which executives as stewards are motivated to act as desired. Principal, besides that, steward behavior will not leave the organization because steward tries to achieve organizational goals. This theory is designed for researchers to examine situations in which executives in the company as servants can be motivated to act in the best way on their principals (Donaldson and Davis, 1989, 1991). Furthermore (Chinn, 2000) Stewardship theory is built on philosophical assumptions regarding human nature: humans are intrinsically trustworthy, able to act responsibly, and have integrity and honesty with others.

\section{Transparency}

Transparency builds on the free flow of information throughout the process of government, institutions, and information that needs to be accessible to interested parties. The information available must be sufficient to be understood and monitored. Transparency means the availability of adequate, accurate, and timely information about public policies and the process of their formation.

Several previous studies that tested clarity based on its characteristics, among others, were conducted by Handayani (2009), which stated that transparency had a positive effect on budget quality. Lucyanda and Sari (2009) state that transparency has a positive effect on budget quality.

\section{Accountability}

Mardiasmo (2004), in his book, states that accountability is understood as the obligation of the agent to provide accountability, present, report, and disclose all activities and activities that are their responsibility to the principal who has the right and authority to hold accountable. Furthermore, Mardiasmo (2009) also states that public accountability consists of two types, 1) vertical accountability, accountability for fund management to a higher authority, for example, the accountability of work units (services) to local governments and accountability of local government to the central government; 2) Horizontal Accountability, accountability to society.
Several previous studies that tested accountability based on its characteristics, among others, were conducted by Lucyanda \& Sari (2009), which stated that public accountability had a positive effect on budget quality. This statement is reinforced by Lawyer (2014), who says that accountability has a positive effect on budget quality. A different opinion was expressed by Putra (2017), who stated that accountability did not affect budget quality.

\section{E. Organizational Commitment}

Luthans (2006) describes that organizational commitment grows because it is created and developed by individuals who work in an organization, and is accepted as value to every new member. The value of members as long as they are in the organization's environment and can consider as a characteristic that distinguishes an organization from other organizations.

Several previous studies that tested organizational commitment based on its characteristics, among others, were carried out by Fitri et al. (2013), which stated that organizational commitment had a positive and significant effect on budget quality. This statement is reinforced by Ogiedu \& Odia (2013), which says that organizational commitment has a positive effect on organizational commitment.

\section{F. Leadership Style}

Leadership style is a method used in the leadership process implemented through one's leadership behavior to influence others to act according to what is determined, motivated to work, and try harder because they like and appreciate the leader; they have higher satisfaction.

\section{G. Budget Quality}

Quality of the budget is the budget that comes from the allocation of the right budget following the regional development plan with the parties involved who can wisely formulate a program based on the aspirations of the community in the budget preparation process. A quality budget can say if the budget already has clear information about cost items, inputs, outputs, and results (Octariani, 2016).

\section{H. Framework}

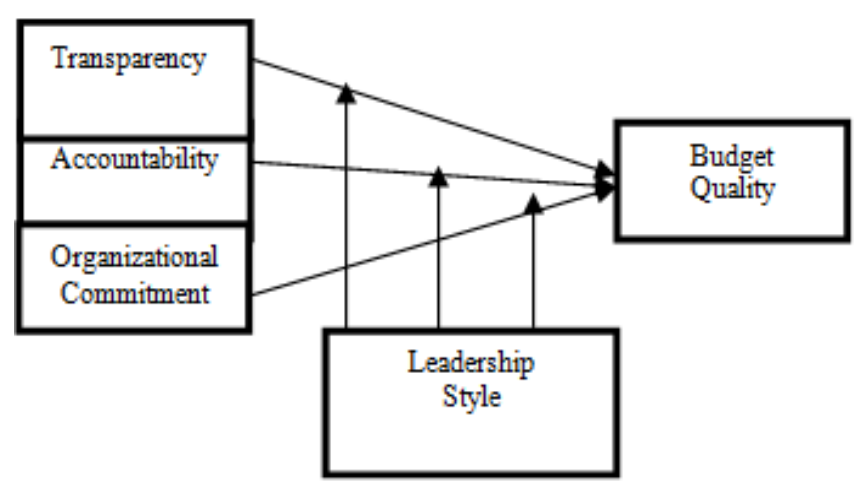

Fig 1 


\section{Hypothesis}

H1: Transparency has a positive effect on budget quality

$\mathrm{H} 2$ : Accountability has a positive effect on budget quality

H3: Organizational commitment has a positive effect on budget quality

H4: Leadership style can moderate budget transparency and quality

H5: Leadership style can moderate accountability and budget quality

H6: Leadership style can moderate organizational commitment and budget quality

\section{RESEARCH METHODOLOGY}

\section{A. Research Approach}

The research was conducted through a scientific approach using a theoretical structure to build hypotheses that required quantitative and statistical testing. This type of research is causal research. According to Kuncoro (2003), in addition to measuring the strength of the relationship between two or more variables, causal studies also show the direction of the relationship between the independent and dependent variables. In other words, causal studies question causal problems.

\section{B. Data Analysis Methods}

The data analysis used in this study is the Partial Least Square (PLS) approach. PLS is a component or variant based Structural Equation Modeling (SEM) equation. PLS is an alternative approach that shifts from a covariancebased to a variant-based SEM approach (Ghozali and Latan 2015).

\section{RESULT}

\section{Descriptive statistics}

Statistical analysis is used to provide an overview of the research variables, which indicate the maximum value, minimum value, average value, and standard deviation of each variable. The variables used in the descriptive statistical calculations are transparency, accountability, organizational commitment, budget quality, and leadership style.

Descriptive statistics obtained from the answers to the questionnaire that returned regarding the research variables are presented in Table 1 as follows:

\begin{tabular}{|c|c|c|c|c|c|}
\hline & N & Min & Max & Mean & Std. Deviation \\
\hline Transparency (X1) & 45 & 3.7 & 5 & 4.3667 & $\mathbf{0 . 4 2 4 8}$ \\
\hline Accountability (X2) & 45 & 3.1 & 5 & 4.2489 & $\mathbf{0 . 5 3 7 9}$ \\
\hline Organizational Commitment (X3) & 45 & 3.5 & 5 & 4.3778 & $\mathbf{0 . 4 1 6 7}$ \\
\hline Leadership Style (Z) & 45 & 3.1667 & 5 & 4.2222 & $\mathbf{0 . 4 7 1 4}$ \\
\hline Budget Quality (Y) & 45 & 3.75 & 5 & 4.3667 & $\mathbf{0 . 4 4 8 6}$ \\
\hline Valid N & 45 & & & & \\
\hline
\end{tabular}

Table 1:- Descriptive statistics

Source: Primary data processed using Excell

Test Results of the Measurement Model (Outer Model)

The outer model test begins by estimating or estimating the parameters, namely by calculating the PLS algorithm with the following results.

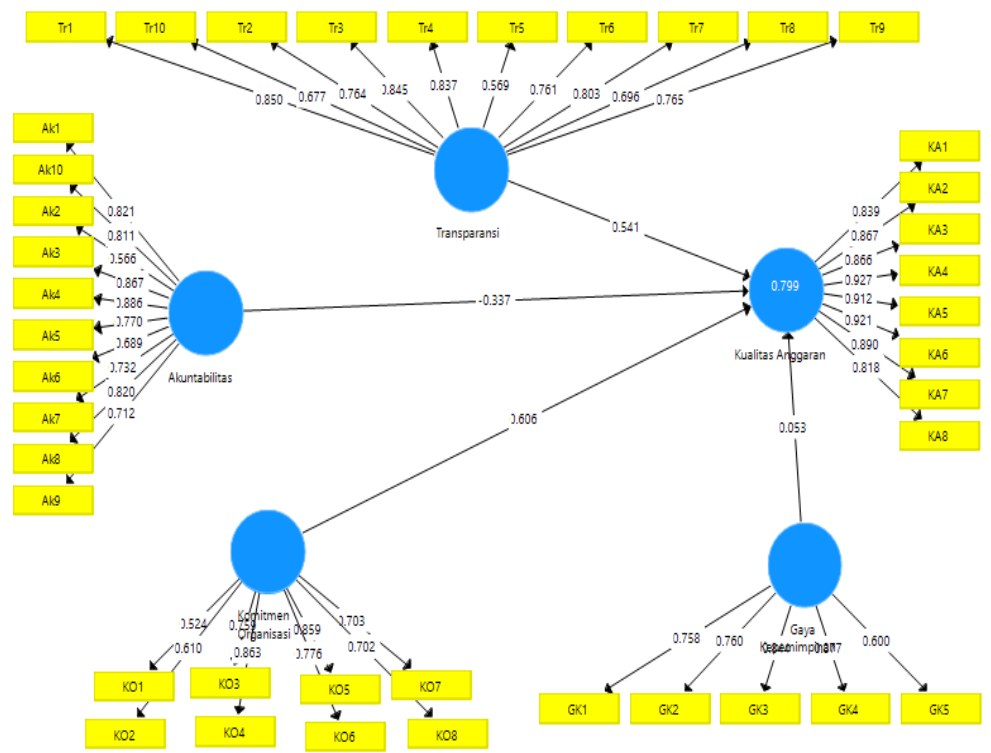

Fig 2:- Display of PLS Algorithm Calculation Output Source: PLS Output Results 


\section{Convergent Validity Test Results}

Based on data calculations with the PLS algorithm method, each variable indicator's loading factor value can be seen in Table 2 below:

\begin{tabular}{|c|c|c|c|}
\hline Variable & Symbol & Loading Factor & Conclusion \\
\hline \multirow[t]{10}{*}{ Transparency (X1) } & $\mathrm{X} 1.1$ & 0.850 & Valid \\
\hline & $\mathrm{X} 1.2$ & 0.764 & Valid \\
\hline & $\mathrm{X} 1.3$ & 0.845 & Valid \\
\hline & $\mathrm{X} 1.4$ & 0.837 & Valid \\
\hline & $\mathrm{X} 1.5$ & 0.569 & Valid \\
\hline & $\mathrm{X} 1.6$ & 0.761 & Valid \\
\hline & $\mathrm{X} 1.7$ & 0.803 & Valid \\
\hline & $\mathrm{X} 1.8$ & 0.696 & Valid \\
\hline & $\mathrm{X} 1.9$ & 0.765 & Valid \\
\hline & $\mathrm{X} 1.10$ & 0.677 & Valid \\
\hline \multirow[t]{10}{*}{ Accountability (X2) } & $\mathrm{X} 2.1$ & 0.821 & Valid \\
\hline & $\mathrm{X} 2.2$ & 0.566 & Valid \\
\hline & $\mathrm{X} 2.3$ & 0.867 & Valid \\
\hline & $\mathrm{X} 2.4$ & 0.886 & Valid \\
\hline & $\mathrm{X} 2.5$ & 0.770 & Valid \\
\hline & $\mathrm{X} 2.6$ & 0.689 & Valid \\
\hline & $\mathrm{X} 2.7$ & 0.732 & Valid \\
\hline & $\mathrm{X} 2.8$ & 0.820 & Valid \\
\hline & $\mathrm{X} 2.9$ & 0.712 & Valid \\
\hline & $\mathrm{X} 2.10$ & 0.811 & Valid \\
\hline \multirow[t]{8}{*}{ Organizational Commitment (X3) } & $\mathrm{X} 3.1$ & 0.524 & Valid \\
\hline & $\mathrm{X} 3.2$ & 0.610 & Valid \\
\hline & $\mathrm{X} 3.3$ & 0.759 & Valid \\
\hline & X3.4 & 0.863 & Valid \\
\hline & $\mathrm{X} 3.5$ & 0.859 & Valid \\
\hline & X3.6 & 0.776 & Valid \\
\hline & $\mathrm{X} 3.7$ & 0.703 & Valid \\
\hline & $\mathrm{X} 3.8$ & 0.702 & Valid \\
\hline \multirow[t]{5}{*}{ Leadership Style (Z) } & $\mathrm{Z1}$ & 0.758 & Valid \\
\hline & $\mathrm{Z2}$ & 0.760 & Valid \\
\hline & $\mathrm{Z3}$ & 0.844 & Valid \\
\hline & $\mathrm{Z4}$ & 0.877 & Valid \\
\hline & $\mathrm{Z5}$ & 0.600 & Valid \\
\hline \multirow[t]{8}{*}{ Budget Quality (Y) } & Y1 & 0.839 & Valid \\
\hline & Y2 & 0.867 & Valid \\
\hline & Y3 & 0.866 & Valid \\
\hline & Y4 & 0.927 & Valid \\
\hline & Y5 & 0.912 & Valid \\
\hline & Y6 & 0.921 & Valid \\
\hline & Y7 & 0.890 & Valid \\
\hline & Y8 & 0.818 & Valid \\
\hline
\end{tabular}

Table 2:- Loading Factor Values Source: PLS Output Results

Based on table 2, it can be seen that all Loading Factor values in the variable have been higher than 0.5, which means that the indicators are declared valid so that they are suitable for use in this study. 
Reliability Test Results

The results of the reliability test on each variable can be seen in Table 3 as follows:

\begin{tabular}{|c|c|c|}
\hline Variable & Composite Reliability & Keterangan \\
\hline Transparency & 0.932 & Reliable \\
\hline Accountability & 0.936 & Reliable \\
\hline Organizational Commitment & 0.901 & Reliable \\
\hline Leadership Style & 0.880 & Reliable \\
\hline Budget Quality & 0.965 & Reliable \\
\hline
\end{tabular}

Table 3:- Composite Reliability Value

Source: PLS Output Results

Based on table 3 , it can be seen that the composite reliability value of each construct is above 0.70 , so it can be stated that the indicators used in this study have met excellent reliability.

\section{Average Variance Extracted (AVE) Value}

AVE values are presented in the following table 4 obtained from the PLS Algorithm output:

\begin{tabular}{|c|c|c|}
\hline Variable & $\begin{array}{c}\text { AVE } \\
\text { value }\end{array}$ & Conclusion \\
\hline Transparency & 0.580 & Valid \\
\hline Accountability & 0.597 & Valid \\
\hline $\begin{array}{c}\text { Organizational } \\
\text { Commitment }\end{array}$ & 0.537 & Valid \\
\hline Leadership Style & 0.599 & Valid \\
\hline Budget Quality & 0.776 & Valid \\
\hline
\end{tabular}

Table 4:- Value of Average Variance Extracted (AVE) Source: PLS Output Results

\section{Cronbach Alpha Value}

Table 5 shows that the Cronbach's Alpha value of each variable is above the 0.700 thresholds, so it can say that all instruments for each variable are reliable, which means consistency when used by other researchers.

\begin{tabular}{|c|c|c|}
\hline Variable & $\begin{array}{c}\text { Cronbach } \\
\text { Alpha }\end{array}$ & Conclusion \\
\hline Transparency & 0.922 & Reliable \\
\hline Accountability & 0.923 & Reliable \\
\hline $\begin{array}{c}\text { Organizational } \\
\text { Commitment }\end{array}$ & 0.877 & Reliable \\
\hline Leadership Style & 0.828 & Reliable \\
\hline Budget Quality & 0.958 & Reliable \\
\hline
\end{tabular}

Table 5:- Cronbach Alpha Value

Source: Research Results, 2020 (data processed using Smartpls)

\section{Effect Size (F2) Test Results} formula:

The effect size calculation can calculate with the

\section{$\mathbf{f}^{2}=\mathbf{R}^{2}$ Moderation Model $-\mathbf{R}^{2}$ Model Without Moderation}

\section{1 - $\mathbf{R}^{2}$ Moderation Model}

Based on the R-Square value that has been calculated using PLS, the effect size value in this research model can calculate as follows:

$$
\mathrm{f}^{2}=\frac{0.855-0.798}{1-0.855}=0.393
$$

Based on the calculation of the effect size above, the variable leadership style contributes significantly to the quality of the budget, amounting to 0.393 .

\section{Prediction Relevance Test Results (Q Square)}

Calculations can be calculated with the Q Square formula:

$$
\mathbf{Q}^{2}=1-\left(1-\mathbf{R}_{1}^{2}\right)-\left(1-\mathbf{R}_{2}^{2}\right)
$$

Based on the R-Square value from the PLS results, the $Q$ value can be calculated in this research model, as follows:

$$
\begin{array}{ll}
\text { Q2 } & =1-(1-0.855)-(1-0.798) \\
& =0.653
\end{array}
$$

Based on the calculation of Q2 square above, it obtains Q2 of 0.653 , which means that the research model has a large predictive capability.

\section{Hypothesis Test Results}

The results of this study indicate that transparency has a positive effect on budget quality so that in this case, hypothesis 1 is accepted. Accountability has a positive effect on budget quality, so hypothesis 2 is accepted. Organizational commitment has a positive effect on budget quality, so hypothesis 3 is accepted. Leadership style cannot moderate the relationship between transparency and budget quality, so hypothesis 4 is rejected. Leadership style can moderate the relationship between accountability to budget quality so that hypothesis 5 is accepted. Leadership style cannot moderate the relationship between organizational commitment to budget quality, so hypothesis 6 is rejected. 


\section{CONCLUSION AND RECOMMENDATION}

\section{A. Conclusions}

The conclusion of this study is transparency has a positive effect on budget quality, accountability has a positive effect on budget quality, organizational commitment has a positive effect on budget quality, leadership style cannot moderate the relationship between transparency and budget quality, leadership style can moderate the relationship between accountability to budget quality, leadership style cannot moderate the relationship between organizational commitment to budget quality.

Based on the above conclusions, the improvements suggested by researchers for further research are to include other variables that have an influence on budget quality, such as Budget Participation, OPD performance, and variables that are thought to have an impact on budget quality performance.

\section{B. Suggestions}

Transparency, accountability, and organizational commitment that affect the quality of the budget must always be improved so that the quality of the budget is better.

$>$ Further research is to be able to expand the research population by using the direct interview method and adding questions in the questionnaire that are appropriate to the issue and in-depth to the research respondents so that the research results' scope becomes broad.

$>$ For further research, it suggests to include other variables that influence the budget quality, such as Budget Participation, OPD performance, and variables that are thought to have an impact on budget quality performance.

\section{REFERENCES}

[1]. Abdullah. S dan Asmara, J.A. (2006). Perilaku Oportunistik Legislatif Dalam Penganggaran Daerah Bukti Empiris atas Aplikasi Agency Theory di Sektor Publik. Simposium Nasional Akuntansi (SNA). Palembang 2006.

[2]. Albassam, Bassam A.(2015). The Influence of Budget Transparency on Quality of Governance. International Journal on Governmental Financial Management. 89109.

[3]. Alegre, J. C. \& Penas, S. L. (2012). Budget Transparency in Local Governments: An Empirical Analysis. Journal of Local Government Studies. Vol 39.Issue 2.

[4]. Andrianto, N. (2007). Good e-Governance: Transparansi dan Akuntabilitas public melalui eGovernment.Bayumedia Publishing. Malang.

[5]. Anggreni, M. Ni, Made., Widanaputra, A. A. G. P., \& Putri, I. A. G M Asri, Puji. (2018). Pengaruh Good Governance dan Kompetensi Sumber Daya Manusia pada Kualitas Laporan Keuangan di Kota Denpasar. E-jurnal Akuntansi Universitas Udayana. Vol 22(1).
ISSN 2302-8556 https://doi.org/10.24843/EJA.2018.v22.i01.p14.

[6]. Anugriani, Rezky Mulya. (2014). Pengaruh Akuntabilitas, Transparansi, Dan Pengawasan Terhadap Kinerja Anggaran Berkonsep Value For Money Pada Instansi Pemerintah Di Kabupaten Bone. Skripsi. Universitas Hasanuddin.

[7]. Arifah, Siti. (2012). Analisis Faktor-Faktor Yang Mempengaruhi Penganggaran Berbasis Kinerja Dengan Peranan CFO Sebagai Variabel Pemoderasi Pada Pemerintah Kota Magelang. Magelang. Fakultas Ekonomi Universitas Tidar Magelang.

[8]. Aziz, M. A. A., Rahman, H. A., Alam, M. M., Said, J.(2015). Enhancement of the accountability of public sectors through integrity system, internal control system, and leadership practices: A Review Study. Procedia Economics and Finance 28 (2015) 163-169.

[9]. Bakar Nur Barizah, Saleh., Zakia., \& Har Sani Mohammad Muslim. (2011). Enchanting Malaysian Public Sector Transparency and Accountability: Lesson and Issues. Malaysia. Journal. The International Islamic University of Malaysia.

[10]. Baron, J. G. (2000). Behavior in Organization Understanding \& managing the human side of work. Edisi 3. Graw Hill, Inc.

[11]. Burns, J.M. (1978). Leadership. Harper \& Row. New York, $N Y$.

[12]. BPKP. (2005). Pedoman Penyusunan Anggaran Berbasis Kinerja. Jakarta: Deputi IV BPKP.

[13]. Brooks, J.L., (2003). Business \& Professional Ethics for Directors, Executive \& Accountants, Third Ed, Thomson-South Western.

[14]. Chin, W. W. (1998). The Partial Least Squares Approach to Structural Equation Modeling. Modern Methods for Business Research. 295- 336.

[15]. Chinn, Richard. (2000). Corporate Governance Handbook. London: Gee Publishing Ltd.

[16]. Christian, Y., Sutaryo. (2015). Penentu jumlah internal control compliance comment dan pengaruhnya terhadap kualitas laporan keuangan pemerintah Daerah di Indonesia. Fakultas Ekonomi dan Bisnis Universitas Sebelas Maret. Jurnal Organisasi dan Manajemen. Vol 11. No.2.

[17]. Chukwuma, L. (2017). International Public Sector Accounting Standards (IPSAS) Adoption And Governmental Financial Reporting In Nigeria- An Empirical Investigation, 3.

[18]. Cimpoeru, M. V. Dan Cimpoeru, V. (2015). Budgetary Transparency-An Improving Factor for Corruption Control and Economic Performance Procedia Economics and Finance. Vol. 27. 579-586.

[19]. De Coster. D.T. dan fertakis. J.P., (186). Budget Induced Pressure and its Relationship to supervisor Behavior. Journal of Accounting Research. Autumn. Hal. 237-246.

[20]. Eckersley, R. (2000). Spiritual, Progres, Meaning, And Values Paper Presented Annual Conference An Spirituality Leadership, And Management Ballarat. 4 December. 
[21]. Ellwood. (1993). Praktek Penyelenggaraan Pemerintah di Daerah. Bima Aksara. Jakarta. 2001.

[22]. Erlina., Saputra, Ari., Muda, Iskandar. (2017). The Analysis of the Influencing Factors of Budget Absorption. International Journal of Economic Research. Volume 14. Number 12.

[23]. Erlina., Tarigan, Zainal Abidin., Muda, Iskandar. (2017). Antecedents of Budget Quality Empirical Evidence from Provincial Government In Indonesia. International Journal of Economic Research. Volume 14. Number 12.

[24]. Fitri, Syarifah Massuki, Unti Ludigdo, dan Ali Djamhuri. (2013). Pengaruh Gaya Kepemimpinan, Komitmen, Organisasi, Kualitas Sumber Daya, Reward, Dan Punishment Terhadap Anggaran Berbasis Kinerja (Studi Empirik Pada Pemerintah Kabupaten Lombok Barat). Jurnal Dinamika Akuntansi Vol. 5, No. 2, September 2013, pp. 157-171.

[25]. Flippo, E. B. (1987). Manajemen Personalia. Jakarta : Erlangga.

[26]. Ghozali, Imam. (2008). Structural Equation Modelling, Edisi II, Universitas Diponegoro, Semarang.

[27]. Ghozali, I. (2013). Aplikasi Analisis Multivariate dengan Program SPSS. Edisi Ketujuh. Semarang : Badan Penerbit Universitas Dipenogoro.

[28]. Ghozali, Imam, Hengky Latan. (2015). Konsep, Teknik, Aplikasi Menggunakan Smart PLS 3.0 Untuk Penelitian Empiris. BP Undip. Semarang.

[29]. Gibson, James, L. (2000). Organisasi, Perilaku, Struktur dan Proses. Edisi ke-5. Cetakan ke-3. Jakarta: Penerbit Erlangga.

[30]. Gibson, James L. et al. (1996). Organisasi: Perilaku, Struktur, Proses. Diterjemahkan oleh Ninuk Adriani. Jakarta: Binarupa Aksara.

[31]. Hanif, Hasrul. (2012). Local politics In Indonesia, 1999-2010 : A Literatur Review. Yogyakarta : JPP UGM.

[32]. Handayani, Bestari Dwi. (2009). Pengaruh Reformasi Penyusunan Anggaran Terhadap Kualitas Apbd Kota Semarang. Jurnal Dinamika Akuntansi Vol 1. No 1, Maret.

[33]. Harlinda. (2016). Analisis Faktor-faktor yang Mempengaruhi Kualitas Informasi Laporan Keuangan Pemerintah Daerah (Studi Empiris pada Pemerintah Kabupaten/Kota di Provinsi Riau). e-Jurnal Universitas Riau, 11(2). ISSN 1907-364X.

[34]. Heald, D.A. (2010). Why is Transparency About Public Expenditure so Elusive. International Review of Administrative Science. 78(1):30-49.

[35]. Hood, C. (2010). Accountability and Transparency: Siamese Twins, Matching Parts, Awkward Couple? West European Politics, 33(5): 989-1009.

[36]. Husein, Umar. (2009). Rencana Kerja Perusahaan Yang Baik. Jakarta: Rajawali.

[37]. Husein, Umar. (2014). Metode Penelitian Untuk Skripsi dan Tesis Bisnis. Edisi-2. Cetakan ke-13. Jakarta : Rajawali Pers.
[38]. Izzaty, Khairina Nur. (2011). Pengaruh Gaya Kepemimpinan Dan Kualitas Sumber Daya Manusia Terhadap Penerapan Anggaran Berbasis Kinerja Badan Layanan Umum (Studi pada BLU Universitas Diponegoro Semarang). Skripsi. Fakultas Ekonomi. Universitas Diponegoro Semarang.

[39]. Kenis, I. (1979). Effects of Budgetary Goal Characteristics on Managerial Attitudes and Performance. The Accounting Review Vol. LIV No. 4. pp 707.

[40]. Kiranayanti, I. A. E., \& Erawati, N. M. A. (2016). Pengaruh Sumber Daya Manusia, Sistem Pengendalian Intern, Pemahaman Basis Akrual Terhadap Kualitas Laporan Keuangan Daerah. EJurnal Akuntansi Universitas Udayana.16(2).12901318.

[41]. Kuncoro, Mudrajad. (2003). Metode Riset untuk Bisnis \& Ekonomi. Jakarta: Erlangga.

[42]. Lalolo krina, Loina. (2003). Indikator Alat Ukur Prinsip Akuntabilitas, Transparansi dan Partisipasi. Jakarta : Badan Perencanaan Pembangunan Nasional.

[43]. Lawyer, C. O. (2014). Cost Control and Accountability For Effective Budget Implementation. Research Journal for Finance and Accounting. Vol. 5 No. 21.

[44]. Lulaj, Enkeleda. (2019). Transparency and Accountability in the Public Budget, Empirical Study (Data Analysis) in Local GovernmentsMunicipalities. University of Peja "Haxhi Zeka," Kosovo.

[45]. Luthans, Fred. (2006). Perilaku Organisasi. (Alih Bahasa V.A Yuwono, dkk). Edisi Bahasa Indonesia. Yogyakarta: ANDI.

[46]. Jensen \& Meckling. (1976). The Theory Of The Firm: Managerial Behaviour, Agency Cost, and Ownership Structure. Journal of Financial and Economics. 3:305-360.

[47]. Lucyanda, Jurica dan Mayla Pramono Sari. (2009). Reformasi Penyusunan Anggaran dan Kualitas Anggaran Belanja dan Pendapatan Daerah. Jurnal Dinamika Akuntansi, Vol. I No.2 September 